\title{
A TEST FOR ABNORMALLY LARGE AMOUNTS OF PARATHYROID HORMONE IN THE BLOOD
}

\author{
By BENGT HAMILTON AND WALTER J. HIGHMAN, JR. \\ (From the Department of Pediatrics, University of Chicago, Chicago)
}

(Received for publication August 1, 1935)

In a previous communication (1) we have described a test for the determination of small amounts of parathyroid hormone. The test is based on the fact that if a soluble calcium salt is given to rabbits by stomach tube in repeated doses, the serum calcium will rise after the first dose while subsequent administrations will have less and less effect. If, however, parathyroid hormone is injected at the beginning of the test, the later administrations of calcium by mouth will have as much, or more, effect in causing a rise of the serum calcium as the first dose. Parathyroid hormone alone will not, of course, cause any rise in the serum calcium of rabbits. This test seems to be sensitive to 5 to 10 units of parathormone.

Since developing this test we have used it extensively for the demonstration of hyperparathyroidism, and we have already published our investigations in animal rickets (2) and in pregnancy (3), in both of which conditions abnormally large amounts of parathyroid hormone were demonstrated in the blood. Since the test has proved to be of some value, we feel that certain modifications which we have introduced may justify a further communication.

The test is made as follows. Thirty cubic centimeters of blood are drawn from the patient and immediately injected intramuscularly in the legs of a rabbit that has fasted for about 12 hours. Just previous to the injection a blood sample has been taken from this rabbit to determine the normal level of calcium in its serum. Immediately after the injection, the rabbit is given by stomach tube 0.1 gram of calcium in the form of calcium chloride ( 0.276 gram of calcium chloride), dissolved in about $10 \mathrm{cc}$. of water. One hour later the administration of calcium by stomach tube is repeated, and again three and five hours after the beginning of the test. Seven minutes after the last two administrations of calcium, blood samples are taken from the rabbit by heart puncture, and calcium determined in the serum.

In interpreting the results, we measure the rise of the blood calcium from the initial value to the highest value obtained at three and five hours. The normal level of calcium in the rabbit's serum is somewhat variable, and we have found that misleading results may be obtained if the initial calcium is very low. We, therefore, discard all tests where the initial value is below $3.00 \mathrm{mM}$. of calcium per liter.

The following are two typical tests. A blood sample was taken from a rabbit by heart puncture, and immediately afterwards $30 \mathrm{cc}$. of blood from a normal woman were injected intramuscularly, about $15 \mathrm{cc}$. in each hind leg. The rabbit was then given $10 \mathrm{cc}$. of a 2.76 per cent calcium chloride solution by stomach tube, and this administration was repeated after one, three, and five hours. Seven minutes after each of the two last administrations of calcium chloride, blood was obtained by heart puncture. In the initial sample, the serum calcium was $3.18 \mathrm{mM}$. per liter, in the last two samples 3.25 , and $3.15 \mathrm{mM}$. per liter. The maximal rise was, then, $0.07 \mathrm{mM}$.

The test performed in the same manner with $30 \mathrm{cc}$. of blood from a woman 17 weeks pregnant gave the following values: initial sample, 3.18 mM.; three hours, $3.78 \mathrm{mM}$; five hours, 3.73 mM.; maximal rise, $0.60 \mathrm{mM}$.

Testing a series of 38 normal indivduals ( 30 women and 8 men) the highest rise obtained was $0.23 \mathrm{mM}$. In numerous cases, however, there was no rise but a decrease of the rabbit's calcium; that is, the three and five hour values were lower than the initial value. The response in the 38 cases may be seen in Table $I$.

We consider a rise of $0.30 \mathrm{mM}$. or more as, probably, being abnormal and indicating the presence in the blood used for injection of more than normal amounts of parathyroid hormone. It must 
TABLE I

Changes in serum calcium

Maximal rise $\mathrm{mm}$.

Decrease or no rise $\ldots \ldots \ldots \ldots \ldots \ldots \ldots 23$

0.01 to $0.05 \ldots \ldots \ldots \ldots \ldots \ldots \ldots \ldots \ldots$

0.06 to $0.10 \ldots \ldots \ldots \ldots \ldots \ldots \ldots \ldots, 4$

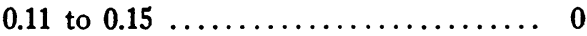

0.16 to $0.20 \ldots \ldots \ldots \ldots \ldots \ldots \ldots \ldots \ldots 2$

0.21 to $0.25 \ldots \ldots \ldots \ldots \ldots \ldots \ldots \ldots \ldots$

be pointed out, however, that this holds only when blood (30 cc.) is being used for the test. If other material is being tested, a series of suitable controls should always be made.
SU M MARY

A method for the determination of abnormally large amounts of parathyroid hormone in the blood is described.

\section{BIBLIOGRAPHY}

1. Hamilton, B., and Schwartz, C., A method for the determination of small amounts of parathyroid hormone. J. Pharmacol. and Exper. Therap., 1932, 46, 285.

2. Hamilton, B., and Schwartz, C., Rickets and hyperparathyroidism. Am. J. Dis. Child., 1933, 46, 775.

3. Hamilton, B., and DaSef, L., Parathyroid hormone in the blood of pregnant women. Tr. A. Am. Physicians, 1935 (In press). 